\title{
PELAKSANAAN KEAMANAN, KESELAMATAN, DAN KEAMANAN KERJA (K3) DI KATERING SERVICE KOTA BANDUNG
}

\author{
Ruly Rahmawati $^{1}$, Ade Juwaedah ${ }^{1}$, Tati Setiawati ${ }^{1}$ \\ Program Studi Pendidikan Tata Boga, Departemen Pendidikan Kesejahteraan \\ Keluarga, Fakultas Pendidikan Teknologi dan Kejuruan, Universitas Pendididkan \\ Indonesia
}

rahmawatiruly31@gmail.com

\begin{abstract}
Abstrak: Peluang terjadinya kecelakaan kerja di industri sangatlah besar. Salah satu upaya pencegahan preventif yang bisa dilakukan ialah dengan melaksanakan program K3. Semakin baik pelaksanaan program K3 yang dimiliki suatu usaha, maka akan semakin baik pula mutu kerja karyawan dan budaya kerja yang tercipta. Namun berdasarkan hasil pengamatan, terdapat suatu industri yang belum melaksanakan program K3 secara optimal. Hal tersebut dapat membuka potensi terjadinya kecelakaan kerja yang dapat merugikan dua belah pihak yaitu, pekerja dan pemilik usaha. Tujuan umum dalam penelitian ini ialah untuk memperoleh gambaran tentang pelaksanaan kesehatan, keselamatan, dan keamanan kerja (K3) di katering tersebut. Metode penelitian yang dilakukan ialah deskriptif dengan pendekatan kualitatif. Lokasi penelitian dilakukan di salah satu katering yang cukup terkenal di Kota Bandung. Secara keseluruhan, hasil penelitian menunjukan bahwa pelaksanaan K3 pada proses katering ini termasuk dalam kategori cukup dilaksanakan. Implikasi yang timbul dari hasil penelitian ini ialah jika pelaksanaan K3 dalam suatu industri tergolong baik, maka peluang terjadinya kecelakaan kerja akan berkurang sehingga proses kerja yang tercipta akan menjamin keselamatan dan keamanan bagi pekerja dan lingkungan.
\end{abstract}

Kata kunci: Kecelakaan kerja, K3, indsutri katering

\section{PENDAHULUAN}

Industri jasa boga (katering) merupakan salah satu industri yang kini perkembangannya sangat pesat. Banyaknya jumlah peminat (masyarakat) yang memakai jasa tersebut membuat produktivitas karyawan ikut meningkat. Produktivitas tenaga kerja adalah kemampuan tenaga kerja dalam menghasilkan barang produksi (BPS, 2019). Tingginya produktivitas tersebut harus dapat menjamin kesejahteraan karyawan, karena perlindungan tenaga kerja dari bahaya dan penyakit akibat kerja atau akibat dari lingkungan kerja sangat dibutuhkan oleh karyawan agar karyawan merasa aman dan nyaman dalam menyelesaikan pekerjaannya (Busyairi, $d k k$, 2014, hlm.2).

Bahaya yang paling umum terjadi di industri ialah kecelakaan kerja. Menurut Peraturan Menteri Tenaga Kerja Nomor 03/Men/98 kecelakaan kerja adalah suatu kejadian yang tidak dikehendaki dan tidak diduga semula yang dapat menimbulkan korban manusia dan atau harta benda. Sebagian besar kecelakaan $(65 \%)$ dikarenakan tingkah laku karyawan yang ceroboh, (35\%) kecelakaan terjadi karena kondisi kerja yang tidak aman, sedangkan cedera paling banya adalah karena terjatuh (Bagyono, 2010, hlm.4). Usaha pencegahan yang dapat dilakukan ialah dengan menyusun, merencanakan, dan melaksanakan program kesehatan, 
keselamatan, dan keamanan kerja (K3).

Kesehatan, Keselamatan, dan Keamanan Kerja (K3) didefinisikan sebagai proses merencanakan dan mengendalikan situasi yang berpotensi menimbulkan kecelakaan kerja melalui persiapan prosedur operasi standar yang menjadi acuan dalam bekerja (Ampuh H, R, 2009) dalam (Jati, Kusuma, dkk. 2010, hlm. 4). Berdasarkan penelitian Tugiono (2009) mengungkapkan bahwa pengelolaan keselamatan, kesehatan kerja, dan lingkungan hidup yang baik adalah landasan utama dalam semua kegiatan operasional. Merujuk pada hal tersebut, penerapan K3 dalam suatu industri menjadi faktor penting yang harus diperhatikan. Dengan tidak menerapkan perilaku K3 di tempat kerja, membuka peluang terjadinya kecelakaan kerja yang akan merugikan karyawan dan pihak perusahaan.

Di lapangan, ditemukan fakta bahwa masih terdapat perusahaan industri jasa boga (katering) yang belum menerapkan prosedur keselamatan kerja secara optimal. Katering tersebut merupakan salah satu katering yang cukup terkenal di Kota Bandung, yaitu Katering VH. Rata-rata jumlah produk yang selalu diproduksi oleh katering ini berkisar antara 200 - 400 pack per hari yang membuat proses produksi makanan sangat padat dan beban kerja yang tinggi. Besarnya beban kerja dan jumlah produksi yang banyak belum berbanding lurus dengan jaminan kesehatan, keselamatan dan keamanan kerja bagi para pegawainya. Dengan tidak menerapkan perilaku K3 di tempat kerja, membuka peluang terjadinya kecelakaan kerja yang akan merugikan pegawai dan katering tersebut.
Penelitian ini bertujuan untuk mendapatkan gambaran umum mengenai pelaksanaan $\mathrm{K} 3$ di suatu katering di Kota Bandung yang bernama katering $\mathrm{VH}$.

\section{METODE}

Penelitian ini menggunakan desain deskriptif dengan pendekatan kualitatif. Penelitian dilakukan selama tiga hari pada bulan Agustus 2019.

Populasi dalam penelitian ini merupakan karyawan katering $\mathrm{VH}$. Pengambilan sample menggunakan teknik sampel purposive dengan mengambil 20 orang karyawan katering yang terdiri dari karyawan katering divisi kitchen, dan karyawan katering divisi service.

Instrumen yang digunakan dalam penelitian ini ialah pedoman observasi, pedoman wawancara, dan studi dokumentasi. Proses analisis data diperoleh dengan menggunakan skala Guttman. Setelah memperoleh hasil penelitian, dilakukan penafsiran data dan analisis untuk mengetahui kategori pelaksanaan K3 di katering $\mathrm{VH}$ dengan mengkonversikan ke dalam skala 100. Tafsiran data yang digunakan telah disesuaikan dengan kebutuhan penelitian menjadi:

Tabel 1 Penskoran dan penafsiran data pelaksanaan

\begin{tabular}{|c|c|}
\hline Persentase & Kriteria \\
\hline $81 \%-100 \%$ & $\begin{array}{c}\text { Sangat } \\
\text { Dilaksanakan }\end{array}$ \\
\hline $61 \%-80 \%$ & Dilaksanakan \\
\hline $41 \%-60 \%$ & $\begin{array}{c}\text { Cukup } \\
\text { Dilaksanakan }\end{array}$ \\
\hline $21 \%-40 \%$ & $\begin{array}{c}\text { Kurang } \\
\text { Dilaksanakan }\end{array}$ \\
\hline
\end{tabular}




\begin{tabular}{|c|c|}
\hline Persentase & Kriteria \\
\hline $0 \%-20 \%$ & $\begin{array}{c}\text { Sangat } \\
\text { Kurang } \\
\text { Dilaksanakan }\end{array}$ \\
\hline & (Riduwan, 2012, hlm. 89)
\end{tabular}

\section{HASIL DAN PEMBAHASAN}

Kesehatan, Keselamatan, dan Keamanan Kerja (K3) diartikan sebagai upaya untuk menjamin jasmani dan rohani tenaga kerja khususnya, dan manusia pada umumnya. Sedangkan industri jasa boga diartikan sebagai industri yang menyediakan makanan dan minuman untuk orang banyak. Industri jasa boga memiliki banyak jenisnya, industri jasa boga yang dijadikan objek penelitian ialah industri katering.

Katering VH merupakan salah satu katering yang cukup terkenal di Kota Bandung. Dari segi pelayanan katering ini masuk dalam klasifikasi jenis usaha golongan A3. Rata-rata jumlah produk yang selalu diproduksi oleh katering ini berkisar antara 200400 pack, dan juga katering ini termasuk ke dalam outside catering.

Penelitian dilakukan untuk memperoleh gambaran khsusus mengenai pelaksanaan $\mathrm{K} 3$ pada saat proses produksi, proses distribusi, dan motivasi internal yang mendorong pelaksanaan K3 oleh karyawan katering tersebut. Berdasarkan hasil penelitian, didapatkan gambaran pelaksanaan K3 secara khusus sebagaimana disajikan pada tabel di bawah ini:
Tabel 2 Pelaksanaan K3 pada proses produksi, distribusi, dan motivasi internal yang mendorong karyawan katering

\section{Pelaksanaan K3}

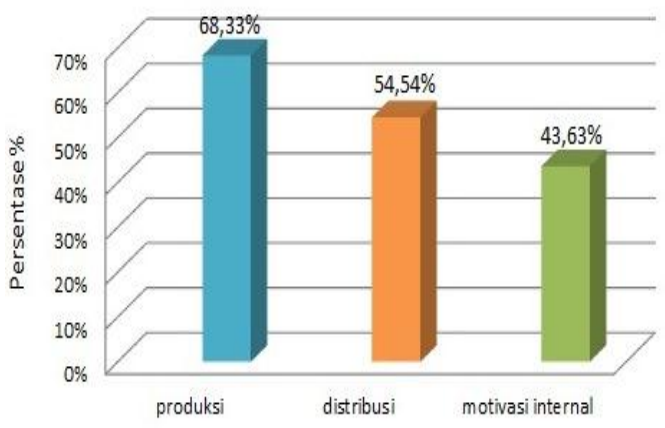

Berdasarkan tabel diatas, menunjukan bahwa lebih dari setengahnya $(68,33 \%)$ pelaksanaan K3 pada saat proses produksi masuk dalam kategori dilaksanakan. Dengan hasil yang telah diperoleh tersebut, dapat diartikan bahwa pelaksanaan K3 pada proses produksi, perlu ditingkatkan kembali. Peningkatan tersebut terfokus pada perilaku karyawan yang masih rendah dalam pemakaian Alat Pelindung Diri. Rudyarti (2017, hlm. 22) mengemukakan bahwa semakin rendah frekuensi penggunaan alat pelindung diri maka semakin besar kesempatan terjadinya kecelakaan kerja. Maka dari itu APD menjadi salah satu syarat keselamatan kerja yang harus diperhatikan oleh tenaga kerja.

Data selanjutnya menunjukan bahwa lebih dari setengahnya $(54,54 \%)$ pelaksanaan K3 pada proses distribusi masuk dalam kategori cukup dilaksanakan. Dengan hasil yang telah diperoleh tersebut, dapat diartikan bahwa pelaksanaan K3 pada proses distribusi perlu ditingkatkan. Peningkatan tersebut terfokus pada penyediaan fasilitas yang lebih optimal oleh perusahaan, agar proses 
distribusi makanan dapat berjalan aman. Menurut Dahlius, $d k k$ (2016), fasilitas kerja karyawan merupakan faktor pendukung bagi kelancaran tugas yang mereka kerjakan, sehingga pekerjaan dapat dikerjakan sesuai dengan yang diharapkan. Maka dari itu, perusahaan sebagai penyedia fasilitas, harus mampu menjamin keselamatan dan keamanan produk dengan mengadakan fasiltas yang memadai.

Data yang ketiga menunjukan kurang dari setengahnya $(43,63 \%)$ motivasi internal yang mendorong pelaksanaan K3 oleh karyawan katering masuk dalam kategori cukup dilaksanakan. Berdasarkan hasil tersebut, dapat diartikan bahwa motivasi internal yang mendorong pelaksanaan K3 oleh karyawan katering sangat perlu ditingkatkan kembali. Namun peningkatan tersebut perlu didorong oleh optimalnya penyediaan fasilitas oleh perusahaan, agar motivasi yang muncul dari para pekerja bisa mewujudkan budaya kerja yang aman dan nyaman. Sejalan dengan yang dikemukakan J. Ravianto (1986: 12) dalam (Hidayah, 2013, hlm. 22) yang menyebutkan bahwa faktor yang mempengaruhi produktivitas karyawan antara lain: "pendidikan dan keterampilan, disiplin dan etika kerja, motivasi, gizi dan kesehatan, tingkat pengahasilan, lingkungan dan iklim, teknologi, manajerial, hubungan antara anggota keluarga, dan sebagainya".

Pedoman wawancara digunakan untuk menjaring data yang kurang terlihat keabsahannya yang diperoleh dari kegiatan observasi diatas. Pedoman wawancara yang dibuat berjumlah 10 pertanyaan yang terdiri dari 2 pertanyaan terkait proses produksi dan 8 pertanyaan terkait motivasi internal yang mendorong pelaksanaan K3 oleh karyawan katering VH. Berikut merupakan pertanyaan yang diajukan dalam pedoman wawancara:

Tabel 3 Pedoman Wawancara

\begin{tabular}{|c|l|}
\hline No & \multicolumn{1}{|c|}{ Pertannyaan } \\
\hline 1 & $\begin{array}{l}\text { Penanganan pertama dalam } \\
\text { memberikan pertolongan }\end{array}$ \\
\hline 2 & $\begin{array}{l}\text { Penggunaan handgloves pada } \\
\text { pekerja yang memiliki alergi }\end{array}$ \\
\hline 3 & Penggunaan APAR \\
\hline 4 & Penyediaan lap/karung \\
\hline 5 & $\begin{array}{l}\text { Selalu memperhatikan rambu- } \\
\text { rambu keselamatan kerja }\end{array}$ \\
\hline 6 & $\begin{array}{l}\text { Memiliki sertifikat kursus } \\
\text { sanitasi higiene }\end{array}$ \\
\hline 7 & $\begin{array}{l}\text { Selalu membaca SOP sebelum } \\
\text { bekerja }\end{array}$ \\
\hline 8 & $\begin{array}{l}\text { Memiliki buku catatan kesehatan } \\
\text { pribadi }\end{array}$ \\
\hline 9 & $\begin{array}{l}\text { Penggunaan masker saat } \\
\text { mengalami sakit ringan }\end{array}$ \\
\hline 10 & $\begin{array}{l}\text { Penggunaan is kotak P3K sebagai } \\
\text { salah satu langkah pertolongan }\end{array}$ \\
\hline
\end{tabular}

$\begin{array}{ccr}\text { Hasil } & \text { wawancara tentang } \\ \text { penanganan } & \text { pertama } & \text { dalam }\end{array}$ memberikan pertolongan, sebesar $65 \%$ responden menjawab "tahu" dan $35 \%$ menjawab tidak tahu. Hasil wawancara tentang penggunaan handgloves pada pekerja yang memiliki alergi, sebesar $15 \%$ responden menjawab "iya memakai karena memiliki alergi", sedangkan $85 \%$ responden lainnya menjawab "tidak memakai karena tidak memiliki alergi". Hasil wawancara tentang penggunaan Alat Pemadam Api Ringan (APAR), sebesar $40 \%$ menjawab "tahu"dengan hasil jawaban kurang sempurna karena responden menyebutkan langkah-langkah penggunaan APAR masih secara garis besarnya seperti "buka segel, tarik cincin/kunci, pegang selang, tekan 
tuas kemudian arahkan pada titik api", sedangkan $60 \%$ menjawab "tidak tahu" dengan hasil jawaban "tidak tahu cara menggunakannnya". Hasil wawancara tentang penyediaan lap/karung goni basah sebagai alternatif alat pemadam api ringan, sebesar $60 \%$ responden menjawab "selalu menyediakan namun hanya lap saja, karena mudah ditemui" dan $40 \%$ responden menjawab "jarang menyiapkan ataupun menyediakan benda tersebut. Hasil wawancara tentang kegiatan selalu memperhatikan rambu-rambu keselamatan kerja di area dapur, sebesar $100 \%$ responden menjawab "tidak pernah memperhatikan karena di area dapur tidak tersedia ramburambu tersebut". Hasil wawancara tentang kepemilikan sertifikat kursus sanitasi higiene, sebesar 5\% responden menjawab "ya memiliki" dan $95 \%$ responden "tidak punya". Hasil wawancara tentang kegiatan selalu membaca Standar Operasional Prosedur (SOP) sebelum bekerja, sebesar 5\% responden menjawab "iya" dan sebesar 95\% responden menjawab "tidak atau jarang membaca karena sudah lupa dan sudah tidak ada lembarannya". Hasil wawancara tentang kepemilikan buku catatan kesehatan pribadi, sebesar $100 \%$ responden tidak memilikinya. Responden menjawab "tidak memiliki". Hasil wawancara tentang penggunaan masker pada saat mengalami sakit ringan, sebesar 20\% responden menjawab "iya selalu pakai", dan sebesar $80 \%$ resnponden menjawab "tidak". Jawaban tidak tersebut terdiri dari $10 \%$ responden lebih memilih istirahat dirumah daripada memaksakan bekerja dan $70 \%$ memilih tidak memakai masker dan agar penyakitnya tidak menular, responden membatasi interaksi dengan rekan kerja. Hasil wawancara tentang penggunaan isi kotak P3K sebagai salah satu langkah pertolongan, sebesar $70 \%$ responden menjawab "ya, selalu menggunakannya" dan sebesar $30 \%$ responden menjawab "terkadang, karena masih menggunakan beberapa obat tradisional".

Berdasarkan hasil data wawancara terkait jawaban pertanyaan nomor satu dan dua menunjukan bahwa pelakssanaan K3 pada proses produksi perlu adanya pembinaan mengenai cara yang dilakukan dalam memberikan pertolongan pertama dan pengetahuan mengenai jenis handgloves yang harus dipakai sesuai pekerjan yang sedang dilakukan. Pembinaan diberikan agar karyawan mengetahui tentang apa yang akan dia hadapi dan dia kerjakan. Menurut Green dalam jurnal yang ditulis (Shiddiq, dkk. 2014, hlm. 114) menyebutkan bahwa peningkatan pengetahuan tidak selalu menyebabkan perubahan perilaku, tetapi pengetahuan sangat penting diberikan sebelum individu melakukan suatu tindakan. Tindakan akan sesuai dengan pengetahuan apabila individu menerima isyarat yang cukup kuat untuk memotivasi dia bertindak sesuai dengan pengetahuannya.

Berdasarkan hasil data wawancara terkait jawaban pertanyaan nomor tiga hingga nomor sepuluh menunjukan bahwa motivasi internal yang mendorong pelaksanaan K3 oleh karyawan perlu ditingkatkan kembali khususnya terkait penggunaan APAR, selalu memperhatikan rambu-rambu keselamatan kerja, memiliki sertifikat kursus sanitasi higiene, selalu membaca SOP sebelum bekerja, memiliki buku catatan kesehatan 
pribadi, dan penggunaan masker saat mengalami sakit ringan. Enam hal diatas, perlu didorong oleh kesadaran dari diri karyawan sendiri. Sujak (1990) dalam jurnal yang ditulis Ayu Brahmasari (2008, hlm.2), mengemukakan bahwa pemahaman motivasi, baik yang ada dalam diri karyawan maupun yang berasal dari lingkungan akan dapat membantu dalam peningkatan kinerja. Dengan begitu, motivasi kerja memiliki peranan penting dalam menentukan kualitas kerja seorang karyawan.

\section{KESIMPULAN}

Secara khusus, pelaksanaan K3 pada saat proses produksi berada dalam kategori dilaksanakan. Pelaksanaan K3 pada proses distribusi berada dalam kategori cukup dilaksanakan, dan motivasi internal yang mendorong pelaksanaan $\mathrm{K} 3$ oleh karyawan katering berada dalam kategori cukup dilaksanakan. Sehingga secara keseluruhan pelaksanaan $\mathrm{K} 3$ di katering VH berada dalam kategori cukup dilaksanakan.

Rekomendasi bagi perusahaan terkait seperti katering VH diharapkan untuk dapat memberikan motivasi ekstrinsik dan pemahaman kepada para pekerja agar dapat melakasanakan program K3 sehingga tercipta lingkunga kerja yang aman bagi dirinya dan lingkungan sekitar. Selain itu, peningkatan pembinaan K3 harus dilaksanakan secara berkelanjutan dengan jangka waktu minimal 3 bulan sekali agar aspek K3 dapat diterapkan dengan optimal.

\section{REFERENSI}

Ayu, Brahmasari, dkk. (2008). Pengaruh Motivasi Kerja, Kepemimpinan dan Budaya Organisasi terhadap Kepuasan Kerja Karyawan serta
Dampaknya pada Kinerja Perusahaan (Studi Kasus pada PT. Pei Hai International Wiratama Indonesia). Jurnal Manajemen dan Kewirausahaan, Vol. 10, No. 2

Badan Pusat Statistik. (2019). Perusahaan Industri Pengolahan (Konsep dan Definisi). Jakarta: bps.go.id

Badraningsih L., Enny Zuhny K. (2015). Kecelakaan Akibat Kerja (KAK) dan Penyakit Akibat Kerja (PAK). Yogyakarta:

Staffnew.uny.ac.id

Bagyono. (2010) Kesehatan, Keselamatan, dan Keamanan Kerja Bidang Perhotelan. Bandung: Alfabeta

Busyairi, Muhammad dkk. (2014). Pengaruh Keselamatan Kerja dan Kesehatan Kerja terhadap Produktivitas Kerja Karyawan. Jurnal Ilmiah Teknik Industri, Vol. 13, No. 2

Dahlius, $d k k$. (2016). Pengaruh Fasilitas Kerja Terhadap

Kepuasan Kerja Karyawan

Pada Pt. Bank Riaukepri

Cabang Teluk Kuantan

Kabupaten Kuantan Singingi. JOM FISIP Vol. 3 No. 2 Oktober 2016

Hidayah. (2013). Pelaksanaan

Program Keselamatan dan

Kesehatan Kerja dalam

Meningkatkan Produktivitas

Kerja Karyawan di PT Tirta

Investama Wonosobo. Skripsi: UNY

Kusuma, dkk. (2010). Pelaksanaan

Program Keselamatan dan

Kesehatan Kerya Karyawan

PT. BITRATEX Industries

Semarang. Jurnal Studi 
Manajemen \& Organisasi, Vol.

7 No. 1 , hlm 3 .

Pemerintah Indonesia. (1998).

Tatacara Pelaporan Dan

Pemeriksaan Kecelakaan.

Jakarta: Peraturan Menteri

Tenaga Kerja Republik

Indonesia

Riduwan. (2007). Skala Pengukuran

Variabel-Variabel Penelitian.

Bandung: Alfabeta

Rudyarti, Edwina. (2017). Hubungan

Pengetahuan Keselamatan Dan

Kesehatan Kerja Dan Sikap

Penggunaan Alat Pelindung

Diri Dengan Kejadian

Kecelakaan Kerja Pada

Pengrajin Pisau Batik Di PT.

$X$. Prosiding Seminar Nasional

Hasil-Hasil Penelitian Dan

Pengabdian Bidang K3 2017

Shiddiq, S, $d k k$. (2014). Hubungan

Persepsi K3 Karyawan Dengan

Perilaku Tidak Aman Di

bagian Produksi Unit IV PT.

Semen Tonasa. Jurnal MIKMI, Juni 2014, hal 110-116

Tugiono, Ali. (2009). Implementasi Keselamatan dan Kesehatan Kerja di PT Bukit Makmur Mandiri Utama Job Shite Head Office Jakarta. Laporan Umum. Jakarta: Universitas Sebelas Maret 